\title{
The Influence of Principal Supervision and Organizational Climate toward Teacher's Performance
}

\author{
by \\ Budiyono \\ SMA Negeri 1 Muara Sugihan, Indonesia \\ Email: budiyonopgri@gmail.com \\ Bukman Lian \\ Universitas PGRI Palembang, Indonesia \\ Email: drbukmanlian@ univpgri-palembang.ac.id \\ Happy Fitria \\ Universitas PGRI Palembang, Indonesia \\ Email: happyfitriamufly@univpgri-palembang.ac.id
}

\begin{abstract}
This research was conducted with the aim to determine the effect of the supervision of the school principal and organizational climate on the performance of high school teachers in the Districts of Muara Sugihan and Makarti Jaya. The method used in this research was quantitative descriptive. The results obtained there is a positive and significant influence of the supervision of the principal on the performance of high school teachers, there is a positive and significant influence of organizational climate on the performance of high school teachers, and there is an influence of school principal supervision and organizational climate on the performance of high school teachers.
\end{abstract}

Keywords: Principal Supervision, Organizational Climate, Teacher's Performance

Introduction:

Based on data from the Global Human Capital Report, published by the World Economic Forum, (2017: 18), in the aspect of education, Indonesia ranks $65^{\text {th }}$ from 130 countries. There is mistake for the educational system in Indonesia, because it lags far behind neighboring countries members of ASEAN. Like Singapore which occupies the $12^{\text {th }}$ position, Malaysia with the $33^{\text {rd }}$ position, then Thailand in the $40^{\text {th }}$ position and the Philippines in the $50^{\text {th }}$ position. This means that an in-depth evaluation of the causes of the low ranking of education in Indonesia is needed according to the World Economic Forum.

Rosser (2018) is a Professor of the University of Melbourne, Australia, stating that Indonesia is still failing to develop education with a comprehensive and integrated system. This is evidenced by the achievement of learning outcomes that are still categorized not of high quality. Some problems that occur in the educational system in Indonesia according to a study conducted by Andrew, the lack of funds in the management of education, human resources were not evenly distributed competencies, the structure of management system is categorized poor (Analisadaily.com, April 26, 2018).

Likewise with the statement made by the World Bank that although the expansion of access to education is done openly to the community but it does not have such a good impact on the quality of the delivery of education in Indonesia (CNN, June 7, 2018). Even the World Bank firmly 
states that an important factor that needs to be considered in order to support the Indonesian economy is the competence possessed by its human resources. To improve human resource competency, one way is through education, which means that the quality of education must also be better (CNN, 07 June 2018).

Therefore, it is stated that Indonesian human resources do not yet have a good education to become a competent workforce and be able to compete. Widodo (2015) further stated that several things that caused education in Indonesia did not yet have optimal quality, including infrastructure facilities that were not evenly distributed and were inadequate; the quality of teachers who have relevant competencies is still minimal; welfare provided to teachers has not been properly fulfilled; student achievement is still low; the opportunity to obtain adequate education is still not so optimal, because the cost of education also tends to be high; the relevance of the delivery of education to the needs has not yet occurred.

Then Yunus et al (2017); Wandasari et al (2019) revealed an important component in education, teachers ranked $14^{\text {th }}$ from 14 developing countries in the world. Yunus et al (2017) further stated that the quality of education in Indonesia is still far from adequate. This is evidenced by the results of the 2015 Teacher Competency Test (UKG), the national average is only 44.5 far below the 75-standard value. Even the pedagogical competencies, which are the main competencies of teachers, have not been encouraging. There are still the majority of teachers whose teaching methods are poor, teaching methods in the classroom are boring. In line with Yaswardi, (2016) the head of South Sumatra LPMP stated that the average UKG score in South Sumatra at the national level was 52.05 while in each regency in South Sumatra where Palembang city the average value of UKG was 5435.

Based on this information, it is clear that a teacher who has competent in his field will have a more positive impact on the development of students to understand the subject matter. The reverse also applies, with the lack of teacher competence, the successful implementation of learning will be difficult to obtain.

From the information available, it is fitting for Indonesia to make changes to the administration of education. Especially to welcome the golden generation in 2045. This will increasingly become important, because the role of education in that era will have a very large impact on the achievements. If there is no improvement from now, the quality of Indonesia's existing human resources will not be able to compete in the global competition. For this reason, system improvements must continue to be made by everyone who is responsible for education. This is confirmed by Pratami (2018), the success of an education is influenced by factors of education personnel (50\%), curriculum (20\%), facilities and infrastructure (20\%), and students $(10 \%)$.

The results of the initial observation in several high schools in the Districts of Muara Sugihan and Makarti Jaya, obtained data from some teachers that showed low performance. There are many things that can cause low performance, including professionalism that has not been done optimally. It is proven by the planning of learning which is not well-administered, the implementation of learning in the classroom is not in accordance with the plans drawn up, and the evaluation conducted is still dominantly done subjectively. The same thing was also revealed from the results of Gusman (2014); Andriani et al (2018); Irmayani et al (2018); Tobari et al (2018) the low performance of teachers is caused by several things, including: (1) teachers lack enthusiasm in completing their tasks related to learning tools, (2) there are teachers who do not yet have teaching programs that good, (3) teacher creativity in choosing learning strategies and methods is 
still lacking or in other words teachers are still dominant using conventional methods, and (4) there are teachers who prioritize their personal interests rather than carrying out their duties as a teacher.

Supardi (2013: 54) states that the expertise possessed by teacher to organize learning to achieve the goals set, and be able to improve the achievements of students is teacher's performance. It can also be said that teacher's performance is the work that can be achieved by a teacher in an educational institution in accordance with their duties and responsibilities in achieving educational goals. In other words, teacher's performance is the work achieved by a teacher in carrying out the tasks assigned to him based on skill, experience and sincerity.

According to Supardi (2013: 27) the ability of performance can be influenced by many factors, among these factors are supervision conducted by the principal and the organizational climate that is formed in educational unit. Regarding the results, teachers are declared successful in organizing learning if they are able to change the behavior of most students towards better mastery of competencies. Problems that occur in the facts and data above are indications of teacher's performance that is still low or not optimal.

The Government of Indonesia through the Minister of Education and Culture has provided clear rules regarding teacher's performance, as contained in ministerial regulation number 22 of 2016. The rules describe that teacher's performance is a standard that must be achieved by teachers to state that the teacher is able to carry out their duties with well. At least, in aspects of learning planning, implementation of learning and evaluate the implementation of learning as a whole. Performance involves a variety of sources become optimal performance. The sources that cause optimal performance according to Sedarmayanti (2014) are individuals, organizations and the external environment. Individual or internal problems in the form of intellectual weakness, psychological weakness, physical weakness, motivation, personality factors, finance, position preparation, and value orientation. External problems in the form of family, economic conditions, political conditions, legal conditions, social values, the labor market, technological changes and unions.

Achievement of learning objectives will depend on the teacher who organizes learning. If the teacher has good competence and skills in carrying out learning, the chances of achieving the learning goals will be very high. Therefore, it is clear that the professionalism of teacher in carrying out their duties will have an impact on the achievement of learning objectives and have implications for the high performance of the teacher himself. Teachers who have competence as educators will be more successful in implementing learning compared to teachers who do not have competence. Success in implementing learning will increase student's learning achievement which will further improve the quality of education. Therefore, efforts to improve the quality of education at all levels must start from the teacher, especially improving the quality of the educational process (Wahyuni, 2018; Fitria, 2018).

Teacher's performance is strongly influenced by many factors, one of which is the climate that occurs in a work unit, in this case called the organization. This is in line with the results of Ramadona (2016) that the organizational climate has a positive and significant influence on the achievement of a teacher's performance.

The existence of a school principal believed have a positive impact on the delivery of education. This is reasonable, because with the existence of the principal, the teacher who teaches will also have a sense of responsibility and oversight, as one of the competencies possessed by a school principal is supervision. These competencies will clearly have an impact on the delivery of education in schools (Maralih, 2014; Apriana et al, 2019; Tobari et al, 2018). The same thing also stated by Gaol, (2017) that improving the performance of a teacher can be through the role 
performed by the principal, because the principal can direct the teacher in the management of learning (Fitria et al, 2017).

Supervision is carried out intensively by the school principal to improve the quality of education in schools. According to Kristiawan, (2017) school principal is likened to a machine in moving activities in school, being a determinant in taking direction or school policies, and being a determinant of how to achieve goals through appropriate strategies. While Darmawati (2015); Khasanah et al (2019); Renata et al, (2018); Murtiningsih et al (2019) state school principal must have manegerial skills so that they can direct and mobilize all available resources to achieve organizational goals, on achieving efficiency and effectiveness of learning so that it becomes a necessity that one of the principal's tasks is supervisors, the work carried out by educational staff.

At present, the supervision carried out by supervisors has an administrative orientation. Therefore, the results of the supervision obtained also illustrate something that happened administratively in the report on paper. Whereas supervision will be more objective if it is also carried out in the implementation or in the process, so these things can be clearly known by supervisor to be followed up.

Based on the description above, as well as the initial observations of researchers at the school that were the object of research. That schools in Muara Sugihan and Makarti Jaya subdistricts are schools with sufficient access far from the city center. Therefore, the phenomena that occur in schools in the city center do not necessarily have the same effect as schools in remote areas. That is why researchers feel it is important to conduct tests to prove the consistency of the results of previous studies in the of Muara Sugihan and Makarti Jaya.

From the description above, the researcher needs to examine the same thing, which is the influence of the supervision of the principal and the organizational climate which is suspected as a determinant of teacher's performance. On this basis the researchers conducted research on the effect of supervision of school principals and organizational climate toward the performance of high school teachers in Muara Sugihan and Makarti Jaya.

\section{Literature Review:}

According to Supardi (2013: 54) teacher performance is a condition that shows the ability of a teacher to carry out their duties and describe the actions displayed by the teacher during the learning process. In addition, Rachmawati (2013: 16) states that teacher's performance is an ability shown by the teacher in carrying out the task or work. Meanwhile, Suharsaputra (2010: 176) states that teacher performance is basically the activities of teachers in carrying out their duties and obligations as a teacher and educator in schools that can describe their work performance in carrying out all of that. Furthermore, according to Uda (2015: 97) defining teacher's performance is an achievement that can be demonstrated by teachers. From the various expert opinions, it was concluded that teacher's performance is a work ability that must be achieved by the teacher in carrying out learning management activities in accordance with the subjects that are mastered by the teacher.

Kristiawan (2019: 1) morphological supervision comes from two syllables super and vision. The word super means rank or more. Whereas the word vision means to realize something that is not actually seen. According to Mushlih and Suryadi, (2018: 41) supervision comes from the word super means up and vision means vision. So etymologically, supervision means a vision from above which describes a process that sees more status. Furthermore, Mushlih and Suryadi (2018: 47) said that education supervision is an activity to foster, guide and direct educational personnel so that educational goals that have been set can be effectively achieved while avoiding 
irregularities. Maryono (2011) these two words, when combined, will provide an understanding that supervision means the activities of someone in the position above to see or monitor someone underneath.

From the description above, it can be said that academic supervision is an effort of a supervisor to help teachers improve the quality of learning inside and outside the classroom. With effective academic supervision, of course the teachers will find it helpful in solving any problems encountered.

Each member in the organization is required to improve its performance in order to be able to carry out the vision and mission of the organization. Human Resources as the most important asset in the organization will undergo a series of work routines and those who become members will provide a perception of the organization (Sopiah, 2008). According to Liliweri (2014) organizational climate is a pattern of behavior, attitudes and feelings that are displayed repeatedly which is used as a characteristic of organizational life. The working climate at school is a situation around the school and a quiet and comfortable atmosphere that is suitable and conducive to learning that can improve academic achievement (Supardi, 2014). While Suharsaputra (2013) defines that organizational climate is very important for the success of an organization and the climate of an organization will be very different from the climate of other organizations, because it is related to the work environment conditions of each organization.

Organizational climate is work conditions that are physical and non-physical and work environment that also influences behavior and which becomes a motivational factor that needs attention from every leader in the organization (Siagian, 2013). In addition, Liana (2012), organizational climate is a means for teachers to work environment with a positive outlook. The organizational climate in schools can move from pleasant to neutral, to unpleasant, but in general school principals, teachers and employees want a pleasant climate because it can lead to better performance (Falahy, 2005).

If climate is beneficial to individual needs, then we can expect behavior towards high goals. Conversely, if climate arises contrary to personal goals, job performance and satisfaction will be reduced (Liana, 2012). Based on the description above it can be concluded that the organizational climate indicator is a concept that describes the quality of the internal environment of the organization that influences the behavior of members of the organization in carrying out its work. Organizational climate that individuals feel positively pleasing will provide a good and effective display of work which will affect the success of the organization. Some of the previous studies that were used as references for this study were Nurhasnawati and Subhan (2018); Pasaribu (2014); Darmawati (2015); Leniwati and Arafat (2017); Brotosedjati (2004); Salwa et al (2019) Gusman (2014); and Sinaga (2010).

\section{Methods:}

This research was conducted in several high schools in Muara Sugihan and Makarti Jaya, Banyuasin, South Sumatera. This research was conducted in June-October 2019. This study used a quantitative approach. Quantitative research method is used to examine a particular population or sample, with statistical data analysis whose purpose is to test a predetermined hypothesis (Sugiyono, 2010). Determination of the sample in this study using proportional random sampling technique. The total number of sample is determined through the Taro Yaname and Slovin formula, this refers to the opinion of Riduwan and Engkos (2011: 49) that the sampling technique used the formula of Taro Yaname and Slovin if the population is known. From the results of these calculations, 58 people were obtained as research samples. Data collection in this study prioritizes 
questionnaire technique and is supported by documentation. The questionnaire used was tested and declared valid and reliable. To analyze the research data, the $t$ test and $F$ test are used, or use simple linear regression and multiple regressions.

\section{Results and Discussion:}

From the results of the data analysis, it is known that in general the principal who became the study sample understood and implemented academic supervision well. Likewise with the organizational climate that was formed, from the analysis conducted by the researchers, it was stated that the climate of the school organization that became the sample of the study was included in both categories. Even for teacher's performance variables, the research sample is included in the category of having high teacher performance.

\section{Data Normality Test Results:}

Testing the normality of the data in this study using the help of the SPSS program, normality testing is done through the Kolmogorov-Smirnov (KS) analysis. The test results that have been carried out on the research data are as follows:

Table 1 Data Normality Test Results

\begin{tabular}{|llr|}
\hline \multicolumn{2}{|c|}{ One-Sample Kolmogorov-Smirnov Test } \\
N & Unstandardized Residual \\
Normal Parameters ${ }^{\text {a,b }}$ & Mean & 58 \\
& Std. Deviation &, 0000000 \\
Most Extreme & Absolute & 1,47901561 \\
Differences & Positive &, 092 \\
Kolmogorov-Smirnov Z & Negative &, 070 \\
Asymp. Sig. (2-tailed) &,- 092 \\
a. Test distribution is Normal. &, 702 \\
b. Calculated from data. &, 707 \\
\hline
\end{tabular}

Based on the table above shows the results of data normality testing, it is concluded that the data in this study are normally distributed. The data normality test above is a test of the residuals of multiple regression. This was done because testing used the Kolmogorov-Smirnov test with the help of the SPSS program. Therefore, normality testing is carried out as a whole data. The conclusion that the data is normally distributed in accordance with predetermined criteria, that if the significance value $>0.05$ then the data is normally distributed. In this study the significance value of 0.707 , which means $>0.05$. Therefore, this research data is declared normal and hypothesis testing can be done with parametric statistical " $t$ " test and " $F$ " test.

\section{Data Linearity Test Results:}

Data linearity testing is one of the classical assumptions testing to see the linearity of a variable being tested. In this study there are two linearity tests, namely the variable academic supervision of school principals with teacher performance and organizational climate with teacher 
performance. The results obtained can be seen in the following table.

Table 2 Results of Academic Supervision Linearity Tests with Teacher Performance

AONATAale

\begin{tabular}{|c|c|c|c|c|c|c|c|}
\hline \multirow{6}{*}{$\begin{array}{c}\text { Teaches' } \\
\text { Performance } \\
\text { *Principal } \\
\text { Supervision }\end{array}$} & & & $\begin{array}{l}\text { Sumd } \\
\text { Swates }\end{array}$ & d & Van Suat: & i & sip \\
\hline & Batwen Goups & (Combinat) & 311,026 & 10 & 3,103 & 8648 & .000 \\
\hline & & Lenentif & 298,747 & 1 & 26,47 & 82,56 & . 000 \\
\hline & & Devition trum Linerity & 14,279 & 9 & 1,587 & int & 905 \\
\hline & Whin Gropess & & 1690,13 & 47 & 3597 & & \\
\hline & T湖 & & 480,069 & 57 & & & \\
\hline
\end{tabular}

Based on the results in the above table, especially in the deviation from linearity section, the significance value is 0.906 , which means it is greater than 0.05 , so the two variables are stated to have a linear relationship. For further testing can be seen in the following table.

Table 3 Results of Organizational Climate Linearity Tests with Teacher's Performance

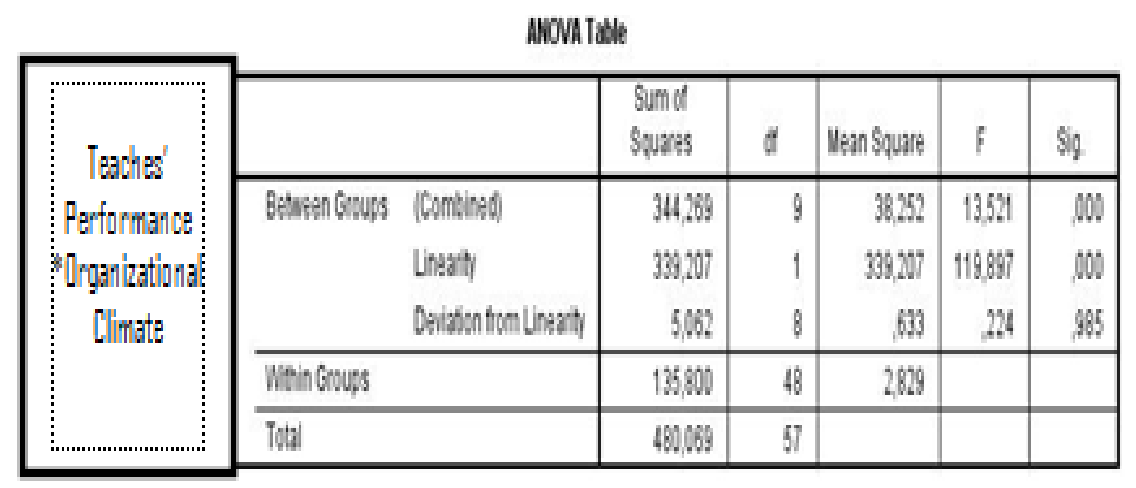

Based on the results of the linearity test for organizational climate variables with teacher performance as shown in the table above, it is concluded that there is a linear relationship evidenced by the deviation from linearity value for the two variables greater than 0.05 , amounting to 0.985 .

\section{Heteroscedasticity Test Results:}

The heteroscedasticity test is a test that assesses whether there is a variance in residual variance for all observations in the linear regression model. If the heteroscedasticity assumption is not met, then the regression model is declared invalid as a forecasting tool. The results of this test of research data are as follows: 


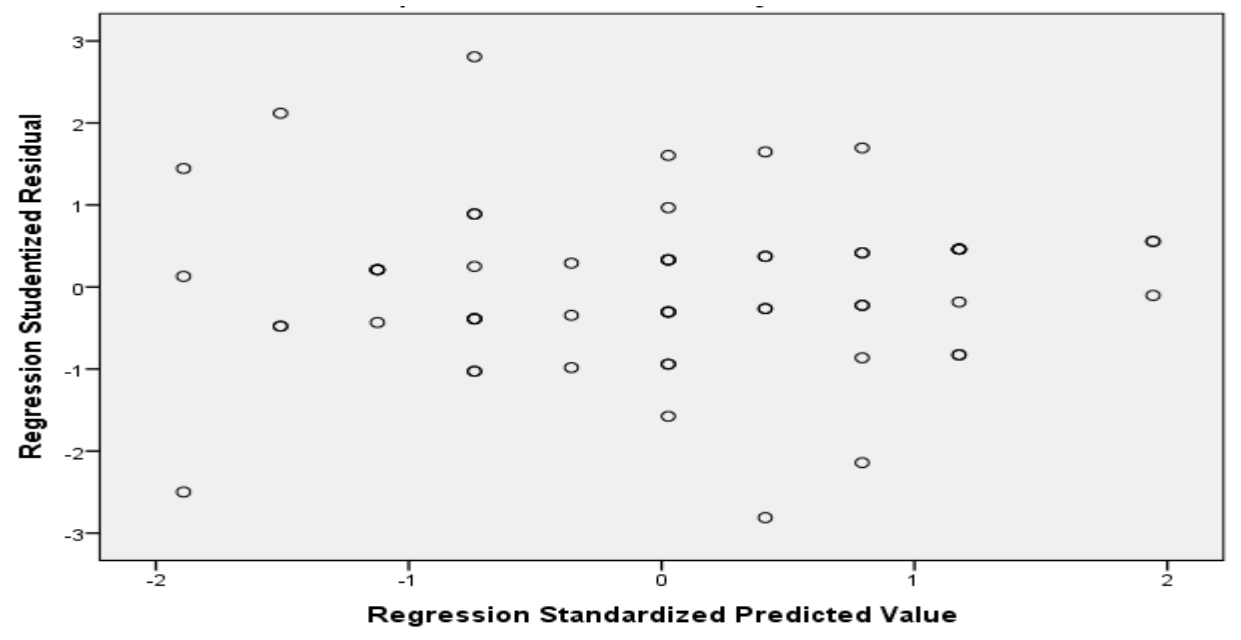

Figure 1 Heteroscedasticity Test Results

Based on the picture above which shows that the distribution of data does not converge at one point, it is proven that there are data in positive and negative regions, and the data do not form certain patterns. Therefore, it is stated that there are no symptoms of heteroscedasticity in this test, so that linear regression testing can be done because the prerequisites in the test have been fulfilled.

\section{Hypothesis $1\left(\mathrm{H}_{1}\right)$ Testing:}

The first hypothesis testing is a test to prove whether there is an influence of the principal's supervision on the teacher's performance. As the formulation of the hypothesis in this study is "there is an influence of the principal's academic supervision on the performance of high school teachers in the Districts of Muara Sugihan and Makarti Jaya".

To test the research hypothesis, a statistical hypothesis is needed. The formulation of the statistical hypothesis in this test is as follows:

$\mathrm{H}_{\mathrm{a}}$ : There is an influence of the principal's supervision on the performance of high school teachers in Muara Sugihan and Makarti Jaya.

$\mathrm{H}_{0}$ : There is no influence of the principal's supervision on the performance of high school teachers in Muara Sugihan and Makarti Jaya

Testing of these statistical hypotheses is done using the "t" test aided by the SPSS program. The results of the analysis that have been carried out are as follows.

\section{Table 4. Hypothesis 1 Test Results ( $\mathrm{X}_{1}$ to $\left.\mathrm{Y}\right)$ Coefficients $^{\mathrm{a}}$}

\begin{tabular}{|l|c|c|c|c|c|}
\hline \multirow{2}{*}{ Model } & \multicolumn{2}{|c|}{$\begin{array}{c}\text { Unstandardized } \\
\text { Coefficients }\end{array}$} & $\begin{array}{c}\text { Standardized } \\
\text { Coefficients }\end{array}$ & \multirow{2}{*}{$\mathrm{T}$} & \multirow{2}{*}{ Sig. } \\
\cline { 2 - 4 } & $\mathrm{B}$ & Std. Error & Beta & & \\
\hline $\begin{array}{l}\text { (Constant) } \\
\text { Supervisi Kepala } \\
\text { Sekolah }\end{array}$ & 22,871 & 3,950 & & 5,790 &, 000 \\
\hline
\end{tabular}

Based on the results of the analysis of the tests conducted, as illustrated in the table above, 
it is known that the value of tcount is 9.521 and significant is 0.000 . If seen from the significance value, the alternative hypothesis for the first hypothesis is accepted, which means that there is a positive and significant influence on the supervision of the principal on the performance of high school teachers in the Districts of Muara Sugihan and Makarti Jaya.

The conclusion is in accordance with the criteria in testing, that the alternative hypothesis $\left(\mathrm{H}_{\mathrm{a}}\right)$ is accepted if the significance $<0.05$. Can also be seen through $\mathrm{t}$-count $\left.=9.521\right\rangle \mathrm{t}$-table $=$ 2.003 which means that the alternative hypothesis ( $\mathrm{Ha}$ ) for hypothesis one is accepted. The magnitude of the relationship or correlation coefficient and the magnitude of the influence or coefficient of determinant of the work environment on teacher performance are analyzed through the SPSS program. The results of the analysis are shown in the following table.

\section{Table 5. Correlational Coefficient and Determinant Coefficient $\left(X_{1}\right.$ to $\left.Y\right)$ Model Summary}

\begin{tabular}{|c|c|c|c|c|}
\hline Model & R & R Square & Adjusted R Square & Std. Error of the Estimate \\
\hline 1 &, $786^{\mathrm{a}}$ &, 618 &, 611 & 1,80931 \\
\hline
\end{tabular}

Based on the results of the analysis shown in the table above, in column $\mathrm{R}$ which means the correlation coefficient is known to be a value of 0.786 interpreted as the magnitude of the relationship of $78.6 \%$ and includes a category of close relationship between the supervision of the principal and teacher performance. In the R square column which is interpreted as the determinant coefficient or the magnitude of influence there is a value of 0.618 which means $61.8 \%$ of teacher performance is influenced by the supervision of the principal, if the test is done individually. While the other $38.2 \%$ is influenced by other factors not analyzed in this study.

\section{Hypothesis $2\left(\mathbf{H}_{2}\right)$ Testing:}

The second hypothesis testing is testing the hypothesis using simple linear regression analysis on organizational climate variables on teacher performance. As the formulation of the hypothesis in this study is "there is an influence of organizational climate on the performance of high school teachers in the Districts of Muara Sugihan and Makarti Jaya".

To test the research hypothesis, a statistical hypothesis is needed. The formulation of the statistical hypothesis in this test is as follows:

$\mathrm{H}_{\mathrm{a}} \quad$ : There is an influence of organizational climate on the performance of high school teachers in the Districts of Muara Sugihan and Makarti Jaya.

$\mathrm{H}_{0} \quad$ : There is no influence of organizational climate on the performance of high school teachers in Muara Sugihan and Makarti Jaya

The statistical hypothesis testing is performed using simple linear regression or by the "t" test aided by the SPSS program. The results of the tests that have been carried out can be seen in the following table. 


\section{Table 6. Hypothesis 2 Test Results $\left(\mathrm{X}_{2}\right.$ against $\left.\mathrm{Y}\right)$ Coefficients ${ }^{\mathrm{a}}$}

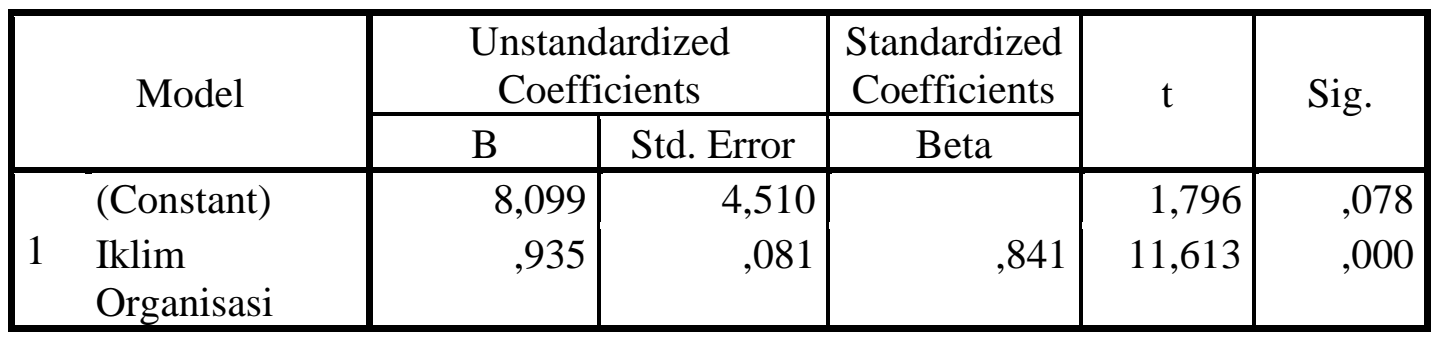

Based on the results of data analysis, values obtained as shown in the table above. From the values in table 4.14 above, it is known that the tcount is 11.613 with a significance of 0,000 . Based on these results then interpreted at a table of 2.003 and a significance level of 0.05 , then an alternative hypothesis for testing the second hypothesis was declared accepted, which means there is a positive and significant influence of the organizational climate on the performance of high school teachers in Muara Sugihan and Makarti Jaya. If tcount $>t$-table and significance obtained $<0.05$, the alternative hypothesis $\left(\mathrm{H}_{\mathrm{a}}\right)$ is accepted, and the statistical hypothesis $\left(\mathrm{H}_{0}\right)$ is rejected. The magnitude of the relationship and the influence of organizational climate variables on teacher's performance are carried out other tests, as shown in the following table.

\section{Table 7. Correlational Coefficient and Determinant Coefficient $\left(X_{2}\right.$ to $\left.Y\right)$ Model Summary}

\begin{tabular}{|c|c|r|r|r|}
\hline $\begin{array}{c}\text { Mode } \\
1\end{array}$ & $\mathrm{R}$ & R Square & Adjusted R Square & $\begin{array}{c}\text { Std. Error of the } \\
\text { Estimate }\end{array}$ \\
\hline 1 &, $841^{\mathrm{a}}$ &, 707 &, 701 & 1,58600 \\
\hline
\end{tabular}

Based on the results of the analysis as seen in the table above, it can be seen that the value of $\mathrm{R}$ or the correlation coefficient or the magnitude of the relationship is 0.841 or $84.1 \%$ which is included in the category of a very close relationship. In the $\mathrm{R}$ square column the value is known to be 0.707 or $70.7 \%$, which means the organizational climate has an influence on teacher performance.

\section{Hypothesis $3\left(\mathbf{H}_{3}\right)$ Testing:}

The third hypothesis testing is testing hypotheses simultaneously or together. Together it is intended that in this study there are two independent variables and one dependent variable, this third hypothesis testing performs the $\mathrm{X}_{1} \mathrm{X}_{2}$ test simultaneously on $\mathrm{Y}$ or test the influence of the principal's supervision and organizational climate together on teacher performance.

To test the research hypothesis, a statistical hypothesis is needed. The formulation of the statistical hypothesis in this test is as follows:

$\mathrm{H}_{\mathrm{a}}$ : There is an influence of school principal supervision and organizational climate on the performance of high school teachers in Muara Sugihan and Makarti Jaya.

$\mathrm{H}_{0} \quad$ : There is no influence of school principal supervision and organizational 
climate on the performance of high school teachers in Muara Sugihan and Makarti Jaya

The test is called multiple linear regression testing, using the " $F "$ test. The results of testing for this hypothesis are as follows:

\section{Table 8. Hypothesis 3 Test Results ( $\mathrm{X}_{1} \mathrm{X}_{2}$ to $\left.\mathrm{Y}\right)$}

ANOVA ${ }^{a}$

\begin{tabular}{|c|c|c|c|c|c|c|}
\hline \multicolumn{2}{|c|}{ Model } & $\begin{array}{l}\text { Sum of } \\
\text { Squares }\end{array}$ & $\mathrm{df}$ & $\begin{array}{l}\text { Mean } \\
\text { Square }\end{array}$ & $\mathrm{F}$ & Sig. \\
\hline \multirow{3}{*}{1} & Regression & 355,382 & 2 & 177,691 & 78,380 &, $000^{b}$ \\
\hline & Residual & 124,687 & 55 & 2,267 & & \\
\hline & Total & 480,069 & 57 & & & \\
\hline
\end{tabular}

a. Dependent Variable

b. Predictors: (Constant)

Based on the results of data analysis in testing the third hypothesis, multiple linear regression testing using the " $F$ " test, the results obtained as shown in the table above. Simultaneous or joint testing is intended to see the effect of supervision of school principals and organizational climate on teacher performance. In column $F$ listed in table 4.16 above there is a value of 78.380 which is the value of Fcount, and when compared with Ftable of 3.16, it is clear that alternative hypotheses for the third test are accepted or the supervision of the principal and organizational climate has a positive and significant effect on high school teacher performance in Muara Sugihan and Makarti Jaya.

Even more clearly it can be seen in the significance value, that in the Sig pond contained in table 4.16 above clearly seen the number 0,000 and then compared with the significance level used in this study which is 0.05 then it is clear that $0,000<0.05$, which means the hypothesis alternative (Ha) for the third hypothesis is accepted and the statistical hypothesis (H0) is rejected. As for the magnitude of the relationship or the correlation coefficient between the three variables and the magnitude of the influence or the coefficient of determinant between the work environment variables and work motivation on performance are in the following table.

Table 9. Correlational Coefficient and Determinant Coefficient ( $\mathrm{X}_{1} \mathrm{X}_{2}$ to $\left.\mathrm{Y}\right)$ Model Summary

\begin{tabular}{|c|c|c|c|c|}
\hline Model & $\mathrm{R}$ & R Square & Adjusted R Square & Std. Error of the Estimate \\
\hline 1 &, $860^{\mathrm{a}}$ &, 740 &, 731 & 1,50567 \\
\hline
\end{tabular}

a. Predictors: (Constant), Organizational Climate, Principal Supervision

Based on the results of data analysis in the framework of testing the third hypothesis, values are obtained as seen in the table above. In the table there is a column $\mathrm{R}$ with a value of 0.860 ; which means the correlation coefficient or the magnitude of the relationship between the principal supervision variable and organizational climate with teacher performance of $86.0 \%$ and included in the category of close relationship. For the determinant coefficient or the magnitude of influence is reflected in the $\mathrm{R}$ square column that is equal to 0.740 , which means that together or 
simultaneously the supervision variable of the school principal and organizational climate has a $74.0 \%$ influence on the performance of high school teachers in Muara Sugihan and Makarti Jaya.

If reviewed, in accordance with the purpose of this research to see whether there is an influence of each independent variable on the dependent variable, it can be explained in more depth that this study is divided into three hypothesis tests. The third hypothesis testing is done to answer the research problem formulation and as proof to strengthen the research objectives.

The first test is testing the hypothesis which states that there is a positive and significant influence on the supervision of school principals on teacher performance. From the test results, it appears that the hypothesis is accepted because the t-count value as a basis for decision making is stated to be greater than $t$ table with a t-value of $9.521>t$-table 2.003 . Then confirmed through the significance value of the test that is $0,000<0.05$ so that it is evident that the supervision of the principal has a positive and significant effect on teacher performance in the Districts of Muara Sugihan and Makarti Jaya.

The second hypothesis testing that is suspected to have a positive and significant influence on organizational climate on teacher performance. The results of the analysis of the data in this study indicate that the alternative hypothesis $\left(\mathrm{H}_{\mathrm{a}}\right)$ for the second test was also accepted, which proved that there was a positive and significant influence of the organizational climate on the performance of high school teachers in Muara Sugihan and Makarti Jaya Districts. This proof is through linear regression analysis with t-count 11.613> t-table 2.003 and seen from the significance value of 0.000 <significant level 0.05 . Therefore an alternative hypothesis for this test was declared accepted and the statistical hypothesis $\left(\mathrm{H}_{0}\right)$ was rejected.

The third test in the implementation of this research is to test simultaneously. Simultaneous testing means testing together the independent variables on the dependent variable. The results obtained from the analysis of research data on testing this hypothesis are proven alternative hypotheses $\left(\mathrm{H}_{\mathrm{a}}\right)$ which say there is a positive and significant influence on the supervision of school principals and organizational climate on the performance of high school teachers in Muara Sugihan and Makarti Jaya otherwise accepted. The conclusion was drawn after taking into account the value of F-count 78.380 and when compared to the F-table of 3.16 and confirmed in the significance of 0,000 <significant level determined at 0.05 .

Thus, the three hypotheses tested in this study were stated to accept alternative hypotheses $\left(\mathrm{H}_{\mathrm{a}}\right)$ and reject the statistical hypotheses $\left(\mathrm{H}_{0}\right)$. The magnitude of the influence of each variable starting from the influence of supervision of school principals on teacher performance by $78.6 \%$, the influence of organizational climate on teacher performance by $84.1 \%$, as well as the influence of supervision of school principals and organizational climate on teacher performance together amounted to $86.0 \%$. Each determinant coefficient or magnitude of influence is included in the high category. While other factors that influence teacher performance in this study were not analyzed.

Regarding the actions taken by the principal as a follow-up to the supervision, so far it has been carried out normatively. Intended normatively because violations or weaknesses that are the findings of supervision can still be tolerated because they do not directly impact on the administration of education fatally. For this reason, sanctions for teachers who are less disciplined from the findings of supervision are carried out in the form of verbal reprimands, this is felt to have more effect on improving teacher performance. Evidenced by the giving of verbal reprimands, discipline is getting better. That is why, the principal does not issue administrative sanctions in the form of a warning letter to teachers who are not yet disciplined.

In connection with the organizational climate contained in the school that is the object of research can be described that the academic climate has been well developed. Even so, there are 
still some notes to be optimized, especially in schools with private status. Researchers found that the organizational climate was already built but the competition built was felt more than coordination. However, this can still be considered reasonable because it does not cause significant disruption to the implementation of education, especially learning in schools.

As described in the research method and research results, in this study there are limitations caused by many factors including the limitations of researchers in terms of research implementation time and research costs. Therefore, the results of this study can be used as a reference in further research but will not be separated from deficiencies. The researcher suggests to the next researcher to first analyze the deficiencies in this study as material for further research.

The results obtained from research that has been done, in principle support the results of research conducted by Sinaga (2010) which produces findings about the significant positive influence of organizational climate on teacher performance. Then Carudin (2011); Irmayani et al (2018); Yuliandri and Kristiawan (2016) produce findings that the climate of school organizations significant effect on teacher teaching performance.

\section{Conclusion:}

There is a positive and significant influence of supervision of school principals on the performance of high school teachers in Muara Sugihan and Makarti Jaya, which means that the alternative hypothesis $\left(\mathrm{H}_{\mathrm{a}}\right)$ in testing hypothesis 1 is accepted. There is a positive and significant influence of organizational climate on the performance of high school teachers in Muara Sugihan and Makarti Jaya, which means that the alternative hypothesis $\left(\mathrm{H}_{\mathrm{a}}\right)$ in testing hypothesis 2 is accepted. There is influence of school principal supervision and organizational climate on the performance of high school teachers in Muara Sugihan and Makarti Jaya, which means that the alternative hypothesis $\left(\mathrm{H}_{\mathrm{a}}\right)$ in testing hypothesis 3 is accepted.

\section{Acknowledgment:}

We would like to express our special thanks and gratitude to Rector Universitas PGRI Palembang and Director of Graduate Program Universitas PGRI Palembang who gave us the support to do this wonderful project. This project was funded independent. Secondly, we would also like to thank our friends and teachers in Graduate Program of Educational Management and SMA Negeri 1 Muara Sugihan who helped us a lot in finalizing this project within the limited time frame.

\section{References}

Analisadaily. (2018). Analisadaily. From https://analisadaily.com/

Andriani, S., Kesumawati, N., \& Kristiawan, M. (2018). The Influence of the Transformational Leadership and Work Motivation on Teachers Performance. International Journal of Scientific \& Technology Research, 7(7).

Apriana, D., Kristiawan, M., \& Wardiah, D. (2019). Headmaster's Competency In Preparing Vocational School Students For Entrepreneurship. International Journal of Scientific \& Technology Research, 8(8). 
Brotosedjati, S. (2012). Kinerja Guru Yang Telah Lulus Sertifikasi Guru Dalam Jabatan [Teacher's Performance that Has Passed Teacher Certification in Position]. JMP 1(2).

Darmawati, Munjin, A., \& Seran, G. (2015). Pengaruh Supervisi Kepala Sekolah Terhadap Kinerja Guru di SMP Negeri 1 Parung Kecamatan Parung Kabupaten Bogor [Effect of Principal Supervision on Teacher Performance]. Jurnal Governansi, 1(1) 13-24.

Fitria, H. (2018). The Influence Of Organizational Culture And Trust Through The Teacher Performance In The Private Secondary School In Palembang. International Journal of Scientific \& Technology Research, 7(7).

Fitria, H., Mukhtar, M., \& Akbar, M. (2017). The Effect of Organizational Structure And Leadership Style on Teacher Performance In Private Secondary School. IJHCM (International Journal of Human Capital Management), 1(02), 101-112.

Gusman. (2014). Hubungan Gaya Kepemimpinan Kepala Sekolah Dengan Kinerja Guru di SMP N Kecamatan Palembayan Kabupaten Agam [Relationship between Principal's Leadership Style and Teacher Performance]. Bahana Manajemen Pendidikan, 2(1).

Irmayani, H., Wardiah, D., \& Kristiawan, M. (2018). The Strategy of SD Pusri In Improving Educational Quality. International Journal of Scientific \& Technology Research, 7(7).

Kesumawati, N., \& Aridanu, I. (2017). Statistik Parametrik Penelitian Pendidikan [Parametric Education Research Statistics]. Palembang: Noer Fikri Offset.

Khasanah, U., Kristiawan, M., \& Tobari. (2019). The Implementation of Principals' Academic Supervision In Improving Teachers' Professionalism in the State Primary Schools. International Journal of Scientific \& Technology Research, 8(8).

Kristiawan, M., Safitri, D., \& Lestari, R. (2017). Manajemen Pendidikan [Educational Management]. Yogyakarta: Deepublish.

Kristiawan, M., Yuniarsih, Y., Fitria, H., \& Refika, N. (2019). Supervisi Pendidikan [Educational Supervision]. Bandung: Alfabeta.

Leniwati, \& Arafat, Y. (2017). Implementasi Supervisi Akademik Kepala Sekolah Untuk Meningkatkan Kinerja Guru [mplementation of Principal Academic Supervision to Improve Teacher Performance]. Jurnal Manajemen, Kepemimpinan dan Supervisi Pendidikan, 2(1) 106-114.

Liana, Y. (2012). Iklim Organisasi dan Motivasi Beprestasi terhadap Kepuasan Kerja dan Kinerja Guru [Organizational Climate and Achievement Motivation for Job Satisfaction and Teacher Performance]. Jurnal Manajemen dan Akuntansi, 1(2).

Liliweri, A. (2014). Sosiologi dan Komunikasi Organisasi [Organizational Sociology and Communication]. Jakarta: Bumi Aksara. 
Maralih. (2014). Peranan Supervisi Dalam Peningkatan Kualitas Pendidikan [The Role of Supervision in Improving the Quality of Education]. Jurnal Qathruna, 1(1) 179-192.

Maryono. (2011). Dasar-Dasar Teknik Menjadi Supervisor Pendidikan [Technical Basics Become an Educational Supervisor]. Yogyakarta: Ar-Ruzz Media.

Murtiningsih, M., Kristiawan, M., \& Lian, B. (2019). The Correlation Between Supervision of Headmaster and Interpersonal Communication With Work Ethos of the Teacher. European Journal of Education Studies.

Mushlih, A., \& Suryadi, R. A. (2018). Supervisi Pendidikan Teori Dan Praktik [Educational Supervision of Theory and Practice]. Bandung: Remaja Rosdakarya.

Nurhasnawati, \& Subhan, M. (2018). Pengaruh antara Iklim Organisasi dan Kepuasan Kerja dengan Organizatioanal Citizenship Behaviour Pada Guru MIN Se Kota Pekanbaru [Influence between Organizational Climate and Job Satisfaction with Organizational Analysis Citizenship Behavior]. IJIEM: Kajian Teori dan Hasil Penelitian, Volume 1 Nomor 2 , 96-111.

Pasaribu, S. E., \& Kariono. (2014). Pengaruh Iklim Organisasi Terhadap Kinerja Pegawai Pada Biro Rektor Universitas Muhammadiyah Tapanuli Selatan [The Effect of Organizational Climate on Employee Performance at the Chancellor's Bureau of the University of Muhammadiyah South Tapanuli]. Jurnal Administrasi Publik, 4(2).

Rachmawati, Y. (2013). Pengaruh Kepemimpinan Kepala Sekolah Terhadap Kinerja Guru [Effect of Principal Leadership on Teacher Performance]. Jurnal Pendidikan Ekonomi IKIP Veteran Semarang, 19-28.

Renata, R., Wardiah, D., \& Kristiawan, M. (2018). The Influence of Headmaster's Supervision and Achievement Motivation on Effective Teachers. International Journal of Scientific \& Technology Research, 7(4).

Riduwan, \& Kuncoro, E. A. (2011). Cara Menggunakan Dan Memaknai Analisis Jalur [How to use and interpret path analysis]. Bandung: Alfabeta.

Salwa., Kristiawan, M., \& Lian, B. (2019). The Effect of Academic Qualification, Work Experience and Work Motivation towards Primary School Principal Performance. International Journal of Scientific \& Technology Research, 8(8).

Sedarmayanti. (2014). Sumber Daya Manusia Dan Produktivitas Kerja [Human Resources and Work Productivity. Jakarta: Mandar Maju.

Siagian. (2013). Manajemen Sumber Daya Manusia [Human Resource Management]. Jakarta: Bumi Aksara.

Sopiah. (2008). Perilaku Organisasi [Organizational Behavior]. Yogyakarta: Andi Offset. 
Sugiyono. (2010). Metode Penelitian Pendidikan (Pendekatan Kuantitatif, Kualitatif dan R\&D) [Educational Research Methods (Quantitative, Qualitative and R\&D Approaches)]. Bandung: Alfabeta.

Tobari., Kristiawan, M., \& Asvio, N. (2018). The Strategy of Headmaster on Upgrading Educational Quality In Asean Economic Community (AEC) Era. International Journal of Scientific \& Technology Research, 7(4).

Wandasari, Y., Kristiawan, M., \& Arafat, Y. (2019). Policy Evaluation of School's Literacy Movement on Improving Discipline of State High School Students. International Journal of Scientific \& Technology Research, 8(4).

Widodo, E. S. (2015). Manajemen Pengembangan Sumber Daya Manusia [Human Resource Development Management]. Yogyakarta: Pustaka Belajar.

World Economic Forum. (2017). Global Human Capital Report. New York: World Economic Forum.

Yuliandri, J., \& Kristiawan, M. (2016). Peran Kepemimpinan Kepala Sekolah Terhadap Peningkatan Kinerja Guru [The Role of Principal's Leadership in Improving Teacher Performance]. Jurnal Dosen Universitas PGRI Palembang.

Yunus, A., Mulyati, T., \& Yunansah, H. (2017). Pembelajaran Literasi [Literacy Learning]. Jakarta: Bumi Aksara. 